\title{
AUTHORITY LEGITIMATION IN CAMPAIGN DISCOURSE OF AMERICAN PRESIDENTIAL CANDIDATES
}

\author{
Boryana Kostova ${ }^{1}$
}

\begin{abstract}
This article addresses legitimation in discourse seen as a complex and multifaceted concept. The specific focus is on authority legitimization which is understood not simply as ethos construction but rather as a claim to rightness, i.e. the claim to be normatively right to perform the speech act. Building upon work on legitimation by van Leeuwen and van Dijk, the article studies intertextuality as one aspect of authority legitimation. The presence of elements of one text in other texts can take various forms and degree of visibility and intensity. Therefore the main purpose of the article is to identify the types and functions of intertextuality. A framework within the scope of Critical Discourse Studies is proposed by which a small corpus of acceptance speeches of contemporary American political leaders is analyzed. The results from the quantitative and qualitative analysis have shown that speakers of different political backgrounds use intertextuality similarly. It is revealed that the most common source of intertextuality is the voice of the political opponent. The main functions of intertextuality in the analyzed speeches are solidarity and credibility building as well as downgrading opposing points of view.
\end{abstract}

Key words: legitimation, intertextuality, authority, political speeches, Critical Discourse Studies

\section{Introduction}

The interest in legitimation arises from concerns expressed by both political scientists and linguists that we live in an era of post-truth and populism which is reflected in the way language is used by politicians, public figures or the elite to justify their actions or to construct their social identity. The election campaigns and referendums in the USA and Britain from the second decade of the $21^{\text {st }}$ century can be taken as instances of the use of language that tends to be based on emotions rather than logos, and ethos that arises from pathos. Another example, taken from the corpus compiled for the purposes of the article, is the statement that "we cannot afford to be so politically correct anymore" (Trump, 2016). It is the evidence of a disturbing trend in using language in the public sphere as it allows verbal attacks and criticism, which are accepted and legitimate means of expression in politics, to spill into insults. Indeed, in

1. Senior Lecturer at Varna Free University, Department of Foreign Language Teaching, Varna, Bulgaria, e-mail: boryana.kostova@vfu.bg, ORCID: 0000-0002-6207-924X 
contemporary multicultural societies, composed of voters of various cultural, social and political backgrounds, it is difficult to find common ground and to build solidarity outside emotions triggered by impoliteness.

Drawing on the understanding that social issues can be explained and possibly opposed by linguistic analysis, the article has two main purposes. It is an attempt to identify instances of legitimization through intertextuality in political discourse and to classify them. It also tries to find out how intertextuality is used by contemporary American politicians as a linguistic strategy to appeal to groups of socially different people, to compensate for the shortage of rational arguments and to legitimize the speaker.

\section{Legitimation in discourse and politics}

Legitimation is a complex phenomenon with three dimensions: socio-political, semiotic and discursive. This means that it works on three levels: (1) as a sociopolitical act or event, for example presidential elections; (2) as a style of behavior, appearance, space organization, multimodal technological resources; (3) as text and talk, discourse, language in use. There is always a complex interplay between these dimensions of legitimation.

In political sciences the term 'legitimation' is intricately connected with the term 'legitimacy' which explains what makes citizens of contemporary democratic societies acknowledge the authority, i.e. the legitimate power of a government and how a government can demand their obedience. The meaning of the term 'legitimacy' has evolved out of Max Weber's classification of political legitimacy (Heywood, 2007, pp. 221-223). The legal-rational legitimacy, typical of contemporary societies, is verbally constructed. Therefore, in order to be legitimate, it is not enough that power is exercised according to established formal rules. Provision of justifications of the formal procedures is needed together with an expression of consent on the part of the governed. In this respect legitimation is a justification of a behavior and its process is enacted by argumentation, i.e. by providing arguments that explain the social actions.

As far as its origin, 'legitimation' refers to conformity to the law or to rules by making something legal or legalized (OED, 2018). In political discourse analysis the term is directly associated with the notion of legitimacy. I. Fairclough and N. Fairclough $(2012$, p. 112) suggest the following definition which includes a citation from Habermas (1984):

Legitimation is a type of argumentative justification, public justification, in which an action can be justified in terms of reasons and those reasons can themselves be justified as collectively accepted and recognized as 'worthy of being recognized'. 
The word 'legitimation' is also used outside the legal and political context and it is synonymous to justification or the ability to be defended with logic (OED, 2018). It is often associated with the speech act of self-defense as the speaker, who seeks legitimation, does it by giving reasons, justification or acceptable motifs for the actions which have been criticized. However, legitimation differs from direct defense or justification in that it does not involve response to a particular accusation or attack. According to Reyes (2011, p. 782) 'legitimation' is "the process by which speakers accredit or license a type of social behavior [...] and the act is related to a goal, which seeks our interlocutor's support or approval". Chilton (2004, pp. 46-47) refers to legitimation as a strategic function closely related to another strategic function - coercion. Legitimation manufactures legitimacy, i.e. the right to be obeyed, discursively by explicit statements, implicatures or various types of arguments. Thus political decisions may be considered legitimate only if they are made in a process which is in line with the standards of argumentation and reasonableness and ,action is justified in terms of values that are themselves capable of public justification" (Fairclough and Fairclough, 2012, p. 243). Much of the work of legitimation is textual, though texts vary considerably in how explicit or implicit legitimation is (Fairclough, 2003). Many researchers express the opinion that legitimation and argumentation are related by their nature while the specifics of the acts of legitimation depend on the variables of context (Mackay, 2015; Martin Rojo \& van Dijk, 1997; Wodak, 2018).

It is widely accepted that any social order requires legitimation - a widespread acknowledgement of the legitimacy of explanations and justifications for how things are done (Fairclough, 2003, p. 219). Yet, Fairclough and Fairclough (2012, p.109) argue that it is not plausible to equate the notions 'legitimation' and 'justification' as 'legitimation' is a particular type of justification and should be the preferred term in the following context of use:

- Legitimation relates to power, particularly the defensive and justificatory practices that are undertaken in order to protect the legitimacy of the actions or an institution. As van Leeuwen (2007, p. 92) puts it "legitimation is the justification of the practice of institutions".

- Legitimation is ideological by nature. It constitutes the instrument through which the boundaries of the ideological space are set within which institutions can work with sufficient social approval.

- Legitimation creates publicly shared and justified beliefs, values and norms due to which a suggested course of action is considered legitimate.

- Legitimation is based on reference to law as obeying a law is a reason that can be publicly justified and gives the opportunity for a social consensus. 
Also, not every persuasive discourse can be referred to as 'legitimation' (van Dijk, 2006, pp. 374-375). Legitimation exists when special conditions or limitations imposed by the context in its social and cognitive aspects are present. These are related to (1) the addresser who must be in a dominant position (member of government or elite in an institutional setting) and the consequences of the communicative act can lead to social inequality if they are only in the interest of the addresser or are at the expense of the addressee; (2) the addressee who might fully or partially lack relevant knowledge or is unable or unwilling to refute the argumentation due to abiding to norms, values and ideologies, strong emotions or his/her social status.

Considering the criteria and the conditions allowing for the act of legitimation, the paper will use the following formulation as a working definition: social and political legitimation can exist when

a powerful group or institution (often the State, the government, the rulers, the elites) seek normative approval for their actions. It does so through strategies that aim to show that such actions are consistent with the moral order, that is, the system of laws, norms, agreements or aims agreed upon by the majority of citizens (Martin Rojo \& van Dijk, 1997, p. 528).

\section{Previous research in the field}

The analysis of legitimation as a discursive practice and the examination of the use of language for legitimation of policies and actions and legitimization of the personal or group authority is conducted from the standpoints of several theoretical frameworks (Chilton, 2004; Martin Rojo \& van Dijk, 1997; Reyes, 2011; van Leeuwen, 2007; van Leeuwen \& Wodak, 1999; Wodak, 2018). The paper will consider only those frameworks which refer directly to the discussion of authority legitimation.

It must be noted that the process legitimation is carried out in two directions: (1) legitimation of an action and (2) legitimation of the personality and discourse of the person seeking institutional legitimation. The latter is referred to as legitimization (Cap, 2006; Chilton, 2004) or self-legitimation/self-legitimating discourse (Martin Rojo \& van Dijk, 1997). It is associated with the discursive establishment or the verbal realization of the speaker's authority, his/herrationality and rightfulness to speak or to be listened to. If the seeker of institutional legitimation lacks institutional power and is not considered trustworthy, the legitimacy of his/her discourse will be doubtful and the justification of the action may be refuted. Legitimization/self-legitimation is achieved through the realization and acknowledgement of the addressee's desires and needs, an emphasis on universal and irrefutable ideological principles, the construction of 
an image of charismatic leadership, and self-praise about personal achievements and positive self-presentation (Cap, 2006, pp. 14-28).

The most widely accepted theoretical frameworks for the analysis of the construction of legitimation in discourse and communication belongs to van Leeuwen (2007) and van Leeuwen and Wodak (1999). The classification characterizes legitimation as an answer to two questions: 'Why should we do this?' or 'Why should we do this in this way?' Four key categories of legitimation are distinguished (Van Leeuwen 2007, p. 92): (1) 'authorization', legitimation by reference to the authority of tradition, custom and law, and of persons in whom institutional authority is vested; (2) 'moral evaluation', legitimation by reference to discourses of value; (3) 'rationalization', legitimation by reference to the goals and uses of institutionalized social action, and to the social knowledge that endow them with cognitive validity; and (4) 'mythopoesis', legitimation conveyed through narratives whose outcomes reward legitimate actions and punish non-legitimate actions. These forms of legitimation can occur separately or in combination. They are realized by specific linguistic resources.

In van Leeuwen's model authority legitimation consists of several subcategories (ibid., pp. 94-97):

Personal authority - The legitimate authority is vested in a person because their position in an institution empowers them within the corresponding social practice. They do not need to justify their actions and can use the phrase 'Because I say so'. In real social practice arguments and reasons are provided because authority is usually vested not in a person but in a social status or a position within an institution. Personal authority legitimation is typically expressed with a verbal process clause, deontic modality and modal phrases such as "it's time to".

Expert authority - legitimacy is provided by expertise rather than status. In the age of professionalism, expertise has acquired authority in many areas although there are multitude expert opinions while problems have more than one expert solution. In political discourse the expertise may be stated explicitly, for example by mentioning credentials, if the expert is well known. It is expressed with a verbal or mental process clause with the expert as the subject.

Role model authority-role models can be either members of the group we belong to or celebrities whose behavior is imitated or beliefs are followed. This type of legitimation plays a particularly important role in advertising and lifestyle media. In political discourse it is achieved when theatre or media celebrities endorse presidential candidates.

Impersonal authority - this refers to the impersonal authorities of laws, rules and regulations, policies and guidelines. They can be subjects of verbal process clauses. The indispensable element in such a clause is the presence of the nouns 'policy', 'regulation', 'rule', 'law' or their cognate adjectives and adverbs, for 
example 'compulsory', 'mandatory', 'obligatory', which appear in impersonal clauses.

The authority of tradition - It is usually assumed that because an action 'is what we always do or have always done', it constitutes a strong argument and can go unchallenged. Therefore, tradition does not need to be made explicit or to be justified. This type of authority is invoked through key words like 'tradition', 'practice', 'custom'.

The authority of conformity - The implicit message with this type of authority is: "Everybody else is/Most people are doing it, and so should you". Even contemporary legislators believe that, if most people are doing something, it cannot be wrong, and should be legalized. It is expressed by an explicit comparison and high frequency modality (the majority of ..., many ...).

Another framework that classifies the linguistic, discursive, communicative and interactional characteristics of legitimation is suggested by Martin Rojo and van Dijk (1997). They examine the discursive strategies of self-legitimation by means of which the discourse which conveys the intended representation is legitimated by itself. The framework includes the following strategies:

Discursive management of power and legitimacy - Differences of power and authority between the addresser and the addressee may be increased, balanced or negotiated. This is achieved through (a) the self-presentation of the speaker in the third person singular which has the effect of identification with an institution, thus the person is transformed into a legitimate person; (b) lexical choice; (c) reproducing authoritative sources and discourses, for example medical or legal jargon thus appropriating the social prestige of the professions.

Delegitimation of other sources of discourse - It is achieved when other sources of information and interpreters of the events are disqualified by challenging their authority. Discrediting is accomplished in two ways: (a) through indetermination, i.e. social actors are represented as anonymous individuals or groups; (b) through depersonalization, i.e. vague reference to criticism when other actors are partially suppressed in discourse by mentioning only their critiques without revealing of the sources of the critique. These forms of discursive concealment and exclusion reduce the authority which affects the legitimacy of the opponents. As a consequence, their discourse, their alternative versions of the events are declared biased and false while the self-legitimating speaker acquires monopoly over the truth.

Moral legitimacy and the rhetoric of objectivity-These are logical consequences of discretization. Unlike the opponent, who misrepresents the events, the selflegitimating speaker claims that what is presented is not his/her personal opinion and subjective interpretation but the real facts. This constructs his/her moral legitimacy as a credible, reliable and trustworthy speaker. The rhetoric 
of objectivity refers to the frequent citation of credible sources, such as experts or authorities, detailed, technical and accurate descriptions of events, the use of numbers which point to truth which cannot be questioned.

Personal commitment - This is a strategy which enhances credibility. Except for the facts and evidence there are other arguments that suggest that the speaker is honest and principled, for instance when the speaker suggests that is personally involved and shares responsibility for the action. This combination of formal responsibility and personal involvement is a move in the overall persuasive strategy of expressing sincerity. This is achieved through the use of personal pronouns in the first person singular.

Manufacturing in-group consensus and solidarity - It is achieved through the polarization of the 'we' and 'they' groups and the inclusive use of the personal pronouns in the first person plural.

Authorized jargon - Jargon is an instrument of social integration. Therefore, it is used to improve in-group communication and to create social cohesion. Professional jargons, on the other hand, are an instrument of exclusion, preventing contact with those in authority, and of manipulation by concealing or mitigating disagreeable facts.

The discussion of authority legitimation must also consider the overall strategy of positive self-presentation and negative other-presentation which is very typical in political discourse. Under the title 'Ideological square of discursive group polarization', this framework suggests an examination of the biased account of the facts in favor of the speaker's own interests, while blaming negative situations and events on the opponents or the Others (van Dijk 2006a, 2006b). The following strategies for legitimation are identified together with their realization in discourse:

- Overall interaction strategies: positive self-presentation and negative other-presentation.

- Macro speech act of accusation and defense implying our 'good' acts and their 'bad' acts.

- Semantic macrostructures: topic selection.

- Local speech acts: statements that prove accusations.

- Local meanings: give many/few details; be general/specific; be vague/ precise; be explicit/implicit; etc.

- Lexical choice: select positive words for Us and negative words for Them.

- Local syntax: active vs passive sentences; nominalizations to (de) emphasize Our/Their positive/negative agency, responsibility. 
- Rhetorical figures: hyperboles vs euphemisms for positive/negative meanings; metonymies and metaphors emphasizing Our/Their positive/ negative properties.

- Expressions: sounds and visuals by emphasizing and ordering (van Dijk, 2006b, p. 373).

Drawing on the literature review it can be concluded that authority legitimization is understood as ethos construction. Speakers can persuade successfully if their speech is based on their own personality or moral traits. According to Aristotle (1986, pp. 46-99) ethos is the principal artistic proof and it can inspire and implant trust in the speaker because we trust honest people generally in everything; and if the issue or its solution is unclear, we trust them unconditionally, without hesitation. This means that when politicians manage to construct trust and admiration of their personality, they increase the credibility of their speech. In our understanding, authority legitimization is much closer, though, to rightness, understood in the sense of one of the validity claims (Habermas, 1984). The claim to rightness is the claim to be normatively right to utter what is being uttered or perform a speech act. This condition establishes a particularity or an aspect of authority that links it to the relative power distribution between the addresser and the addressee. Thus, authority legitimization constructs the positive image of the addresser together with the right to speak, to behave, to make decisions the way he/she does.

One of the linguistic tools used to express this particularity of authority is intertextuality. Intertextuality of a text is the presence within it of elements of other texts and potentially other voices than the author's own. These may be related in various ways, for example dialogued with, assumed, rejected and so on (Fairclough, 2003, p. 218). The relationship between the texts can take many forms like parodies, retelling, summary, irony. The most common and pervasive form of intertextuality is reported speech. Fairclough (1992) distinguishes between manifest intertextuality - quotation, citation and paraphrase - and constitutive intertextuality - generic features which do not leave an obvious trace from the source. In American presidential discourse Austermühl (2014, pp. 27-39) finds out that the relations and interactions between presidential texts themselves and between presidential texts and other culturally significant texts take place at five levels. The following types of intertextuality are identified which vary in their degree of visibility and intensity:

- Discursive intertextuality is characterized by uniform text, sentence, and word lengths, predictable use of active and passive voices, standardized syntactical and pronominal choices.

- Hypertextuality is the relationship between texts that is based on shared textual and argumentative patterns. 
- Thematic intertextuality is the repetition or continuous presence of a set number of topics.

- Generic intertextuality functions on the level of the text type or genre, while parallels originate from the belonging to the same groups of texts.

- Material intertextuality refers to allusions, both implicit and explicit, to other texts through quotations or paraphrases, references to people and sites of memories. It is the most easily identifiable type of intertextuality.

Given the ceremonial and epideictic aspect of campaign speeches, together with the deliberative one, there is high prevalence of material intertextuality in this type of discourse. There are four main types of allusions (Austermühl, 2014, pp. 221-255):

Quotational allusions - appear with quotation marks, italicization, spacing or the integration of a foreign language element.

Titular allusions - reference to the title of a work, e.g. a book, painting, journal, song or film. In the American context such sacred documents are the Declaration of Independence and the U.S. Constitution as well as some semisacred documents like John Winthrop's sermon aboard the Arabella, the socalled "American Covenant", and speeches of American presidents.

Onomastic allusions - name-related references which include references to personal names, names of places (toponyms) and significant historical events and eras. Among the group of persons or moral authorities that are quoted directly or indirectly are the Founding Fathers or Framers. George Washington is a fixture among onomastic allusions. Other national icons alluded to are Lincoln, Kennedy, Franklin D. Roosevelt and Jefferson. References to other political leaders such as Winston Churchill or Martin Luther King Jr. mostly take the form of concrete quotational allusions but can also appear as imitations of the structural, stylistic, or formal nature of previous presidential speeches. Allusions that refer to the collective memory of the American public are the American Revolution, the Civil War, the Great Depression, the two World Wars, the Cold War, and September 11. Textual references to God, the Bible and religious and moral authorities are quite common. Voices of regular, Main Street Americans is a quotational device found in abundance in campaign speeches. It is implemented in quotations from personal letters written by ordinary American citizens to the candidate.

Pseudointertextual allusions - fictitious statements referring to and suggesting the presence of a pre-text that actually does not exist, for example negations, fictitious or rhetorical questions, references to unidentified addressees. The formula "those who say" or "some say" allow the speaker to enter into a rather 
one-sided dialogue with invisible opponents which gives the argumentation a quasi-dialogical character.

\section{Research Questions}

The study aims to illustrate how speakers highlight the correctness of their own positions and make the audience view their stance as commonsense, valuable and trustworthy. The paper tries to find the answers to two important questions:

(1) How is authority legitimation achieved via intertextuality?

(2) Which types of intertextuality are employed in order to justify one's own political stance and to reject opposing points of view?

\section{Methods}

The study is conducted within the broad field of Critical Discourse Studies. It is a useful theoretical framework as it focuses on the deconstruction of the hidden relations between the participants in communication. Those relations are usually encoded and embedded into the way language is used and refer to social hierarchy and power, be it only symbolic power. From the perspective of communication, legitimation is one rare instance where the participants simultaneously possess and lack power. On the one hand, the speaker, who as part of the elite has the real power in society, needs the support of the audience to gain or maintain the political power. The audience, on the other hand, has only the symbolic power to accept or to refute the presented arguments if they are worthy enough in terms of societal values.

In order to study this specific situation of the use of language, quantitative and qualitative analyses were carried out, while the instances of intertextuality were manually collected. The study uses primarily qualitative data, paying close attention to linguistic characteristics of intertextuality.

\section{Data Analysis}

The data for this study consists of four political speeches delivered during two election campaigns by two about to be American presidents from the Democratic and the Republican Party respectively - Barack Obama and Donald Trump - and their political opponents - John McCain and Hilary Clinton. The corpus consists of 19,567 words. It covers the acceptance speeches of these four candidates, all of whom had not participated in previous election campaigns. Being novice in the contest for the highest elected post within the political structure of the USA, places the speakers at equal footing although they belong to different political parties. There is an expectation that they will employ various rhetorical strategies to legitimize themselves for this new role. 
The acceptance speeches of the four political leaders were delivered at the party conventions in 2008 and 2016. These were huge televised events attended in person by thousands of people and followed by many more domestically and internationally. Acceptance speeches are program speeches which present the candidate's political strategy and plans. They are charged with the potential to change the audience's perception of a candidate's personality and influence their preference for the candidates. A televised speech, uploaded on social media such as YouTube may be a powerful channel for politicians to demonstrate their authority and increase their likability, and at the same time discredit their opponents.

\section{Results/Key findings}

\section{Justifying one's own political position}

The study illustrates how presidential candidates use intertextuality to justify their own position and arguments and uphold the value of their own political stance. This dialogism or polyphonic features of the discourse is achieved through six main sources using the voices of ordinary citizens, family members, authoritative speakers or sources, numbers and research, onomastic allusions of place, historical event, important document, self-reference. By deploying these voices either through direct quotations or indirectly through summaries, narratives or allusions, each candidate highlights not only the correctness of their own political position but mainly the likability and moral value of their personality. Thus, the audience is induced to view their stance as commonsense, valuable and trustworthy.

\section{The voice of citizens}

The voice of citizens is represented through the stories that were told or reported to the candidate earlier. Citizens usually have a specific identification, i.e. they are referred to by their names and surnames without honorific titles. The reason for the presence of these narratives within the speech is to show the sources of candidates' motivation and to present him/her as caring for the issues that concern ordinary citizens. These instances of empathy position him/her as a nurturant parent, to use Lakoff's (1996) term, and as a very ordinary person standing for the most powerful position.

(1) I don't know what kind of lives John McCain thinks that celebrities lead, but this has been mine. These are my heroes. Theirs are the stories that shaped me. And it is on their behalf that I intend to win this election and keep our promise alive as President of the United States. (Obama, 2008)

(2) After the four days of this convention, you've seen some of the people who have inspired me, people who let me into their lives and became a 
part of mine, people like Ryan Moore and Lauren Manning. They told their stories Tuesday night.

I first met Ryan as a 7-year old. He was wearing a full-body brace that must have weighed 40 pounds because I leaned over to lift him up. Children like Ryan kept me going when our plan for universal health care failed and kept me working with leaders of both parties to help create the Children's Health Insurance Program that covers 8 million kids in our country.

Lauren Manning, who stood here with such grace and power, was gravely injured on 9/11. It was the thought of her and Debbie St. John who you saw in the movie and John Dolan and Joe Sweeney and all the victims and survivors that kept me working as hard as I could in the Senate on behalf of $9 / 11$ families and our first responders who got sick from their time at ground zero.

I was thinking of Lauren, Debbie and all the others 10 years later in the White House Situation Room when President Obama made the courageous decision that finally brought Osama bin Laden to justice.

And in this campaign, I've met many more people who motivate me to keep fighting for change. And with your help, I will carry all of your voices and stories with me to the White House. (Clinton, 2016)

(3) I fight for Americans. I fight for you. I fight for Bill and Sue Nebe from Farmington Hills, Michigan, who lost..... lost their real estate investments in the bad housing market. Bill got a temporary job after he was out of work for seven months. Sue works three jobs to help pay the bills.

I fight for Jake and Toni Wimmer of Franklin County, Pennsylvania. Jake...

Jake works on a loading dock, coaches Little League, and raises money for the mentally and physically disabled. Toni is a schoolteacher, working toward her master's degree. They have two sons. The youngest, Luke, has been diagnosed with autism. Their lives should matter to the people they elect to office. And they matter to me. And they matter to you.

I fight for the family of Matthew Stanley of Wolfeboro, New Hampshire.

Matthew died serving our country in Iraq. I wear his bracelet and think of him every day. I intend to honor their sacrifice by making sure the country their son loved so well and never returned to remains safe from its enemies. (McCain, 2008) 
(4) My heart just swelled when I saw Anastasia Somoza representing millions of young people on this stage. Because we changed our law to make sure she got an education. (Clinton, 2016)

Candidates show compassion not only for ordinary citizens but also for citizens performing their duties and risking their lives.

(5) A president should respect the men and women who risk their lives to serve our country...including Captain Khan and the sons of Tim Kaine and Mike Pence, both Marines. (Clinton, 2016)

(6) And thanks -- thanks to the leadership of a brilliant general, David Petraeus, and the brave men and women he has the honor to command... [applause]...that -- that strategy succeeded, and it rescued us from a defeat that would have demoralized our military, risked a wider war, and threatened the security of all Americans. (McCain, 2008)

In some speeches the response to the particular grievances goes beyond the mere expression of compassion. The speech act of blaming unknown personalities for killings creates a negative emotion which is directly related to the justification of a political position and intentions. This frames the candidate as a Strict Father, as defined by Lakoff (1996).

(7) On Monday, we heard from three parents whose children were killed by illegal immigrants Mary Ann Mendoza, Sabine Durden, and my friend Jamiel Shaw. They are just three brave representatives of many thousands who have suffered so gravely. Of all my travels in this country, nothing has affected me more deeply than the time I have spent with the mothers and fathers who have lost their children to violence spilling across our border, which we can solve. We have to solve it. (Trump, 2016)

The voice of citizens may be generalized with no specific identification except for the city or state they live in or an allusion of it.

(8) A nation of whiners? Tell that to the proud auto workers at a Michigan plant who, after they found out it was closing, kept showing up every day and working as hard as ever, because they knew there were people who counted on the brakes that they made. Tell that to the military families who shoulder their burdens silently as they watch their loved ones leave for their third or fourth or fifth tour of duty. These are not whiners. They work hard and give back and keep going without complaint. These are the Americans that I know. (Obama, 2008)

In the following excerpt the speaker alludes to the city of New Orleans, devastated by a natural disaster: 
(9) This country is more decent than one where a woman in Ohio, on the brink of retirement, finds herself one illness away from disaster after a lifetime of hard work.

This country is more generous than one where a man in Indiana has to pack up the equipment he's worked on for twenty years and watch it shipped off to China, and then chokes up as he explains how he felt like a failure when he went home to tell his family the news.

We are more compassionate than a government that lets veterans sleep on our streets and families slide into poverty; that sits on its hands while a major American city drowns before our eyes. (Obama, 2008)

The same strategy of including voices of citizens without giving their specific identification is used in combination with invoking fear through lexical choice of nouns, verbs and adjectives which denote death.

(10) America was shocked to its core when our police officers in Dallas were so brutally executed. In the days after Dallas, we have seen continued threats and violence against our law enforcement officials. Law officers have been shot or killed in recent days in Georgia, Missouri, Wisconsin, Kansas, Michigan and Tennessee.

On Sunday, more police were gunned down in Baton Rouge, Louisiana. Three were killed, and three were very very badly injured. [...]

Every action I take, I will ask myself: does this make better for young Americans in Baltimore, in Chicago, in Detroit, in Ferguson who have as much of a right to live out their dreams as any other child America? $[\ldots]$

Only weeks ago, in Orlando, Florida, 49 wonderful Americans were savagely murdered by an Islamic terrorist. This time, the terrorist targeted LGBTQ community - no good and we're going to stop it. (Trump, 2016)

\section{Voice of family members through narratives}

Voices of the candidates' family members are present as narratives in all the speeches. They function as a frame within which the candidate positions himself/herself as a coherent person who has developed in moral terms due to his/her endurance, ambition and personal strength, who is capable of balancing the personal and professional life and is very authentic exposing his/her human nature. 
(11) So let me tell you. The family I'm from, well, no one had their name on big buildings. My family were builders of a different kind, builders in the way most American families are. They used whatever tools they had, whatever God gave them and whatever life in America provided and built better lives and better futures for their kids.

My grandfather worked in the same Scranton lace mill for 50 years.

Because he believed that if he gave everything he had, his children would have a better life than he did. And he was right. My dad, Hugh, made it to college, he played football at Penn State and enlisted in the Navy after Pearl Harbor. When the war was over, he started his own small business printing fabric for draperies. I remember watching him stand for hours over silkscreens. He wanted to give my brothers and me opportunities he never had, and he did.

My mother, Dorothy, was abandoned by her parents as a young girl. She ended up on her own at 14 working as a housemaid. She was saved by the kindness of others. Her first-grade teacher saw she had nothing to eat at lunch, and brought extra food to share the entire year.

The lessons she passed on to me years later stuck with me. No one gets through life alone. We have to look out for each other and lift each other up. And she made sure I learned the words from our Methodist faith: Do all the good you can for all the people you can in all the ways you can as long as ever you can.

So I went to work for the Children's Defense Fund, going door-to- door in New Bedford, Massachusetts on behalf of children with disabilities who were denied the chance to go to school. I remember meeting a young girl in a wheelchair on the small back porch of her house. She told me how badly she wanted to go to school. It just didn't seem possible in those days. And I couldn't stop thinking of my mother and what she'd gone through as a child. (Clinton, 2016)

(12) In this journey, I'm so lucky to have at my side my wife Melania and my wonderful children, Don, Ivanka, Eric, Tiffany, and Barron: you will always be my greatest source of pride and joy. And by the way, Melania and Ivanka -- did they do a job? My Dad, Fred Trump, was the smartest and hardest working man I ever knew. I wonder sometimes what he'd say if he were here to see this and to see me tonight.

It's because of him that I learned, from my youngest age, to respect the dignity of work and the dignity of working people. He was a guy most comfortable in the company of bricklayers, carpenters, and electricians 
and I have a lot of that in me also. I love those people.

Then there's my mother, Mary. She was strong, but also warm and fairminded. She was a truly great mother. She was also one of the most honest and charitable people I have ever known, and a great judge of character. She could pick 'em out from anywhere.

To my sisters Mary Anne and Elizabeth, my brother Robert and my late brother Fred, I will always give you my love you are most special to me. I have loved my life in business. (Trump, 2016)

(13) My friends, when I was growing up, my father was often at sea, and the job of raising my brother, sister and me would fall to my mother alone. Roberta McCain gave us her love of life, her deep interest in the world, her strength, and her belief that we're all meant to use our opportunities to make ourselves useful to our country. I wouldn't be here tonight but for the strength of her character. (McCain, 2008)

(14) My friends, when I was 5 years old, a car pulled up in front of our house. A Navy officer rolled down the window and shouted at my father that the Japanese had bombed Pearl Harbor. I rarely saw my father again for four years. (McCain, 2008)

(15) Because in the faces of those young veterans who come back from Iraq and Afghanistan, I see my grandfather, who signed up after Pearl Harbor, marched in Patton's Army, and was rewarded by a grateful nation with the chance to go to college on the GI Bill.

In the face of that young student who sleeps just three hours before working the night shift, I think about my mom, who raised my sister and me on her own while she worked and earned her degree; who once turned to food stamps but was still able to send us to the best schools in the country with the help of student loans and scholarships.

When I listen to another worker tell me that his factory has shut down, I remember all those men and women on the South Side of Chicago who I stood by and fought for two decades ago after the local steel plant closed.

And when I hear a woman talk about the difficulties of starting her own business, I think about my grandmother, who worked her way up from the secretarial pool to middle-management, despite years of being passed over for promotions because she was a woman. She's the one who taught me about hard work. She's the one who put off buying a new car or a new dress for herself so that I could have a better life. She 
poured everything she had into me. And although she can no longer travel, I know that she's watching tonight, and that tonight is her night as well. (Obama, 2008)

\section{The voice of numbers and research}

Another external resource for dialogism is the voice of numbers and research, or the language of objectivity. The notion of numbers and research, or objective professional expertise, refers to something authoritative in a specific field such as academia or science. By quoting this voice, speakers can earn credibility for their political ideology and justify their own position. However, the eight numbers mentioned in excerpt (16) do not create the impression that the speaker needs external, professional authority to extend his own. Rather the speaker tends to reaffirm himself as the exclusive source of credible and truthful information. This effect is achieved by mitigating or hiding the source of the statistics. Also, the selection of particular statistics associated with death and destruction intensifies the negative pathos of the speech by creating fear and disgust. This makes it possible for the speaker to legitimize himself as a hero capable of creating prosperity out of destruction.

(16) It is finally time for a straightforward assessment of the state of our nation. I will present the facts plainly and honestly. We cannot afford to be so politically correct anymore. [...] We will honor the American people with the truth, and nothing else. These are the facts: [...]

Homicides last year increased by 17 percent in America's fifty largest cities. That's the largest increase in 25 years. In our nation's capital, killings have risen by 50 percent. They are up nearly 60 percent in nearby Baltimore. [...]

The number of police officers killed in the line of duty has risen by almost 50 percent compared to this point last year. Nearly 180,000 illegal immigrants with criminal records, ordered deported from our country, are tonight roaming free to threaten peaceful citizens. [...]

Excessive regulation is costing our country as much as $\$ 2$ trillion a year, and we will end it very very quickly. We are going to lift the restrictions on the production of American energy. This will produce more than $\$ 20$ trillion in job creating economic activity over the next four decades. (Trump, 2016)

\section{The authoritative speaker's voice}

The heavyweight speaker's voice represents the voice of political leaders or national heroes. These figures from the nation's past and present serve as moral authorities, models of patriotism. The use of this type of intertextuality serves 
to position the candidate within a tradition of thought and behavior, to present the current actions as a natural continuation of the past. In the following excerpt the speaker undertakes an interesting form of indirect quotation. She first quotes a song from a very popular Broadway show running just at the time of the campaign and thus creates the context to introduce the real historical figures worth quoting at that occasion. These are the founders of the American nation or the leaders of the American Independence War and authors of the American constitution, Alexander Hamilton being one of them.

(17) And though we may not live to see the glory, as the song from the musical "Hamilton" goes, let us gladly join the fight, let our legacy be about planting seeds in a garden you never get to see. That's why we're here, not just in this hall, but on this earth. The Founders showed us that and so have many others since. They were drawn together by love of country and the selfless passion to build something better for all who follow. (Clinton, 2016)

Other moral authorities with whom speakers identify and on whose endorsement they rely are presidents of the country, political leaders and public figures. Therefore, their voices are present in the speech through indirect quotation, i.e. reporting and summarizing their words. The function of this instance of intertextuality is to legitimize the candidate as worth being endorsed due to the support from important public figures she managed to gain.

(18) We heard the man from Hope, Bill Clinton, and the man of hope, Barack Obama. America is stronger because of President Obama's leadership. And I'm better because of his friendship. We heard from our terrific vice president, the one and only Joe Biden. He spoke from his big heart about our party's commitment to working people as only he can do.

And first lady Michelle Obama reminded us that our children are watching. And the president we elect is going to be their president, too. (Clinton, 2016)

(19) Now, remember what the president said last night: Don't boo; vote! (Clinton, 2016)

Another instance of intertextuality is the reference to the memorable and endurable ideas of President Kennedy. First, the heavyweight speaker's voice is introduced through a direct quotation. Then, as the paragraph develops, there is an indirect quotation or rather an allusion to Kennedy's historic words known from his inaugural address: "And so, my fellow Americans: Ask not what your country can do for you - ask what you can do for your country". In this way, Kennedy inspired and challenged every American to contribute in some way to the public good, to commit themselves to service. Similarly, the speaker 
legitimizes himself by applying the same ideas of societal and individual responsibility within a contemporary context.

(20) And Democrats, we must also admit that fulfilling America's promise will require more than just money. It will require a renewed sense of responsibility from each of us to recover what John F. Kennedy called our "intellectual and moral strength." Yes, government must lead on energy independence, but each of us must do our part to make our homes and businesses more efficient. Yes, we must provide more ladders to success for young men who fall into lives of crime and despair. But we must also admit that programs alone can't replace parents; that government can't turn off the television and make a child do her homework; that fathers must take more responsibility for providing the love and guidance their children need. Individual responsibility and mutual responsibility - that's the essence of America's promise. (Obama, 2008)

Authoritative speakers can be represented by spiritual leaders and activists such as Martin Luther King Jr. Interestingly, despite the fact that his voice is obvious through a direct and indirect quotation, the name is absent from the text. It is only inferred by references such as "a young preacher from Georgia speaking his dreams". The listener or reader of the speech must rely on their cultural and historical knowledge in order to recognize the source of the intertextuality which is the iconic speech known under the title "I have a Dream" delivered on the steps of Lincoln Memorial in Washington D.C. in front of a numerous gathering and is associated with the civil rights movement of Afro-American citizens in the USA. Being of Afro-American origin himself, the speaker identifies himself with the preacher and his ideas for unity and social equality which should characterize American society today. The speaker goes beyond this instance of intertextuality and continues his speech relying on interdiscursivity, i.e. undertaking a style that resembles one of a preacher instead of a political candidate.

(21) And it is that promise that forty five years ago today, brought Americans from every corner of this land to stand together on a Mall in Washington, before Lincoln's Memorial, and hear a young preacher from Georgia speak of his dream.

The men and women who gathered there could've heard many things. They could've heard words of anger and discord. They could've been told to succumb to the fear and frustration of so many dreams deferred.

But what the people heard instead - people of every creed and color, from every walk of life - is that in America, our destiny is inextricably linked. That together, our dreams can be one. 
"We cannot walk alone," the preacher cried. "And as we walk, we must make the pledge that we shall always march ahead. We cannot turn back." (Obama, 2008)

The speakers may quote someone from their own party. In such cases, speakers typically quote a party leader or someone very close to them as in the excerpt, i.e. President Kennedy's wife. The function of this instance of intertextuality is to stress ideological coherence within the party. It is important for the speaker to bring in the voice of a more authoritative person from their party to show that their political stance lies within a tradition and is supported by someone with more political authority.

(22) I can't put it any better than Jackie Kennedy did after the Cuban Missile Crisis. She said that what worried President Kennedy during that very dangerous time was that a war might be started not by big men with self-control and restraint, but by little men, the ones moved by fear and pride.

America's strength doesn't come from lashing out. It relies on smarts, judgment, cool resolve and the precise and strategic application of power. And that's the kind of commander in chief I pledge to be.

And if we're serious about keeping our country safe, we also can't afford to have a president who's in the pocket of the gun lobby. (Clinton, 2016)

\section{Onomastic allusion - name/place/ historical event/ important document}

Onomastic allusion is a form of indirect intertextuality by which in a very elegant, but powerful way a cognitive frame is triggered by the mention of a name, place, historical event or an important document. In the following excerpt the speaker introduces the names of two American presidents supported by the Democratic Party. Thus, the speaker seeks solidarity and endorsement by making the audience recall the record and the success of the mentioned presidents. Franklin D. Roosevelt is considered as one of the nation's greatest presidents because he managed to fight the worst economic crisis in U.S. history and lead the country during WWII. Kennedy was another widely accepted American leader who served at the height of the Cold War until his assassination. Presidents Lincoln and Reagan are associated with the abolition of slavery after the Civil War and the end of the Cold War, respectively. The ship Mayflower is connected to the early history of the land, especially the first immigration wave from Europe. These facts are not made explicit but can be recollected by those possessing enough historical knowledge. Otherwise the names remain only as symbols of patriotism and responsibility. 
(23) We are the party of Roosevelt. We are the party of Kennedy. So don't tell me that Democrats won't defend this country. Don't tell me that Democrats won't keep us safe. The Bush-McCain foreign policy has squandered the legacy that generations of Americans -- Democrats and Republicans - have built, and we are here to restore that legacy. (Obama, 2008)

(24) We're going to recover the people's trust by standing up again to the values Americans admire. The party of Lincoln and Reagan is going to get back to basics.

In this country, we believe everyone has something to contribute and deserves the opportunity to reach their God-given potential, from the boy whose descendants arrived on the Mayflower to the Latina daughter of migrant workers. We're all God's children, and we're all Americans (McCain, 2008)

Onomastic allusions refer to the mention of places and historical events as well. In excerpt (24) the toponym Philadelphia unlocks a cognitive frame connected to the early history of the country - it was in the city of Philadelphia that the Declaration of Independence was signed, a document that marked the beginning of the American nation. Although American society today is multicultural, this reference establishes common ground with American citizens even with differing political views, cultural and religious background.

(25) My friends, we've come to Philadelphia, the birthplace of our nation, because what happened in this city 240 years ago still has something to teach us today. We all know the story, but we usually focus on how it turned out and not enough on how close that story came to never being written at all.

When representatives from 13 unruly colonies met just down the road from here, some wanted to stick with the king and some wanted to stick it to the king.

The Revolution hung in the balance, and somehow they began listening to each other, compromising, finding common purpose. And by the time they left Philadelphia, they had begun to see themselves as one nation. That's what made it possible to stand up to a king. That took courage, they had courage. Our Founders embraced the enduring truth that we are stronger together. (Clinton, 2016)

The Declaration of Independence and the Scripture are dominant sources of inspiration for patriotism and are often used to invoke a sense of solidarity. Excerpt (26) constitutes an indirect quotation of a very famous line from the historical document while excerpt (27) is a variation of Hebrews chapter 10: 
verse 23. The latter is used as a natural move towards the conclusion of the speech in the style of American Jeremiad.

(26) We're dedicated to the proposition that all people are created equal and endowed by our creator with inalienable rights. No country no country ever had a greater cause than that. And I wouldn't be an American worthy of the name if I didn't honor Senator Obama and his supporters for their achievement. (McCain, 2008)

(27) Let us keep that promise - that American promise - and in the words of Scripture hold firmly, without wavering, to the hope that we confess. (Obama, 2008)

Speakers often show alignment with typical American values or call for national unity. They achieve it by mentioning or quoting important documents like the Constitution or national symbols like the traditional motto of the USA appearing on the Great Seal. The phrase "a more perfect union" belongs to the preamble of the U.S. Constitution and reveals an aspiration at building a balanced and fair society.

(28) Tonight we've reached a milestone in our nation's march toward a more perfect union. The first time that a major party has nominated a woman for president! (Clinton, 2016)

(29) Now America is once again at a moment of reckoning. Powerful forces are threatening to pull us apart. Bonds of trust and respect are fraying. And just as with our Founders, there are no guarantees. It truly is up to us. We have to decide whether we will all work together so we can all rise together. Our country's motto is E Pluribus Unum, out of many we are one. Will we stay true to that motto? (Clinton, 2016)

Not all allusions have a positive connotation. Some of them include negative evaluation as they refer to places of tragedies, war, and terrorist attacks. The mention of the World Trade Center, the Boston Marathon and Vietnam create an image of destruction and suffering. These can be considered as metonymical expressions, that is, the places where the events happened are used to stand for those events themselves. Thinking of the tragic events associated with these places, the speakers have two objectives: (a) to justify their own position for taking certain action against terrorist organizations; (b) to establish one's own authority as a war hero, veteran, survivor of a war.

(30) The damage and devastation that can be inflicted by Islamic radicals has been proven over and over - at the World Trade Center, at an office party in San Bernardino, at the Boston Marathon, and a military recruiting center in Chattanooga, Tennessee. And many, many other locations. (Trump, 2016) 
(31) In Vietnam, where I formed the closest friendships of my life, some of those friends never came home with me. (McCain, 2008)

(32) Long ago, something unusual happened to me that taught me the most valuable lesson of my life. I was blessed by misfortune. I mean that sincerely. I was blessed because I served in the company of heroes and I witnessed a thousand acts of courage, and compassion, and love. On an October morning, in the Gulf of Tonkin, I prepared for my 23rd mission over North Vietnam. I hadn't any worry I wouldn't come back safe and sound. I thought I was tougher than anyone. I was pretty independent then, too. I liked to bend a few rules and pick a few fights for the fun of it. (McCain, 2008)

\section{Self-reference}

Self-reference is a specific type of intertextuality. Its function is to uphold the positive self-evaluation and credibility of the speaker.

(33) Recently I have said that NATO was obsolete, because it did not properly cover terror, and also, that many of the member countries were not paying their fair share. As usual, the United States has been picking up the cost. Shortly thereafter, it was announced that NATO will be setting up a new program in order to combat terrorism -- a true step in the right direction. (Trump, 2016)

Referring to oneself in the third person singular distances the speaker from the current situation presenting him in a more formal way. This relates to the power relations between the speaker and his audience where the speaker gains authority through the post he aspires to.

(34) My opponent, on the other hand, wants to put the great miners and steel workers of our country out of work and out of business - that will never happen with Donald Trump as President. Our steelworkers and our miners are going back to work again. With these new economic policies, trillions of dollars will start flowing into our country. (Trump, 2016)

\section{Rejecting opposing points of view}

\section{The opponents' voice}

Attacking or criticizing one's opponent is a common practice in political discourse. Speakers may bring up their opponent's previous utterances and point out their inconsistencies as well as negatively evaluate their political stance. This criticism functions as a platform for presenting one's own arguments as rational, appropriate and moral. The opponent's voice can be heard either through direct 
quotation, or much more frequently as indirect reporting paired with negative evaluation. The opponent is usually referred to by name and surname, even only by first name, without the use of honorifics. This discursive strategy contributes to the negative frame within which the opponent is presented and to the speech act of blaming. Here are some examples:

(35) Now, Donald Trump, Donald Trump says, and this is a quote, "I know more about ISIS than the generals do." No, Donald, you don't. He thinks he knows more than our military because he claimed our armed forces are a disaster. (Clinton, 2016)

(36) Well, we heard Donald Trump's answer last week at his convention. He wants to divide us from the rest of the world and from each other. He's betting that the perils of today's world will blind us to its unlimited promise. He's taken the Republican Party a long way, from morning in America to midnight in America. He wants us to fear the future and fear each other. (Clinton, 2016)

(37) Now, you didn't hear any of this, did you, from Donald Trump at his convention? He spoke for 70-odd minutes - and I do mean odd - and he offered zero solutions. But we already know he doesn't believe these things. No wonder he doesn't like talking about his plans. You might have noticed I love talking about mine. (Clinton, 2016)

(38) My opponent [Hilary Clinton] has called for a radical 550\% increase in Syrian -- Think of this. Think of this. This is not believable, but this is what's happening -- refugees on top of existing massive refugee flows coming into our country under President Obama. She proposes this despite the fact that there's no way to screen these refugees in order to find out who they are or where they come from.

I only want to admit individuals into our country who will support our values and love our people. Anyone who endorses violence, hatred or oppression is not welcome in our country and never ever will be. (Trump, 2016)

(39) That is why Hillary Clinton's message is that things will never change... never ever. My message is that things have to change - and they have to change right now. (Trump, 2016)

(40) Senator Obama wants our schools to answer to unions and entrenched bureaucrats. I want schools to answer to parents and students. (McCain, 2008)

(41) Washington's been talking about our oil addiction for the last thirty years, and John McCain has been there for twenty-six of them. In that time, he's said no to higher fuel-efficiency standards for cars, no to 
investments in renewable energy, no to renewable fuels. And today, we import triple the amount of oil as the day that Senator McCain took office. Now is the time to end this addiction, and to understand that drilling is a stop-gap measure, not a long-term solution. Not even close. (Obama, 2008)

(42) For while Senator McCain was turning his sights to Iraq just days after 9/11, I stood up and opposed this war, knowing that it would distract us from the real threats we face. When John McCain said we could just "muddle through" in Afghanistan, I argued for more resources and more troops to finish the fight against the terrorists who actually attacked us on 9/11, and made clear that we must take out Osama bin Laden and his lieutenants if we have them in our sights. John McCain likes to say that he'll follow bin Laden to the Gates of Hell - but he won't even go to the cave where he lives. [...] John McCain stands alone in his stubborn refusal to end a misguided war. (Obama, 2008)

Excerpt (42) presents an interesting reference to the political opponent, rather an imaginary dialogue with the opponent. Despite the adversarial nature of the election campaign, it is a case in which the opponent is referred to with as much respect and admiration as possible. This is visible from the honorific "Senator" used before the name and the content of the message with which the speaker acknowledges that the rules of the election campaign are rarely based on tolerance and respect. This positions the candidate if not as a combating figure, at least as an honest person.

(43) And, finally, a word to Senator Obama and his supporters. We'll go at it -- we'll go at it over the next two months -- you know that's the nature of this business -- and there are big differences between us. But you have my respect and my admiration. Despite our differences, much more unites us than divides us. We are fellow Americans, and that's an association that means more to me than any other. (McCain, 2008)

\section{Citizens' voice}

Citizens' grievances and sufferings, and their unsolved social problems can be used as a reason to blame the political opposition for negligence. These narratives, which are usually told to create negative emotions through the choice of words denoting death, also pave the way for the speaker to present himself as a protector and savior.

(44) One such border-crosser [illegal immigrant] was released and made his way to Nebraska. There, he ended the life of an innocent young girl named Sarah Root. She was 21 years-old, and was killed the day after graduating from college with a 4.0 Grade Point Average. Number one 
in her class. Her killer was then released a second time, and he is now a fugitive from the law.

I've met Sarah's beautiful family. But to this Administration, their amazing daughter was just one more American life that wasn't worth protecting. No more. One more child to sacrifice on the order and on the altar of open borders. (Trump, 2016)

(45) Every day I wake up determined to deliver for the people I have met all across this nation that have been neglected, ignored, and abandoned.

I have visited the laid-off factory workers, and the communities crushed by our horrible and unfair trade deals. These are the forgotten men and women of our country. And they are forgotten, but they're not going to be forgotten long. People who work hard but no longer have a voice. I am your voice! I have embraced crying mothers who have lost their children because our politicians put their personal agendas before the national good. (Trump, 2016)

\section{The authoritative speaker's voice - national leader/ hero/ important document}

In order to refute the arguments of the political opponent, candidates present quotations from other sources such as respectful political leaders, historical figures as a counter argument to the opponent's words. This is noticeable in the examples:

(46) He [Trump] wants us to fear the future and fear each other. Well, you know, a great Democratic President Franklin Delano Roosevelt came up with the perfect rebuke to Trump more than 80 years ago during a much more perilous time: The only thing we have to fear is fear itself! (Clinton, 2016)

(47) Americans don’t say “I alone can fix it." We say "we'll fix it together!”

And remember, remember, our Founders fought a Revolution and wrote a Constitution so America would never be a nation where one person had all the power. 240 years later, we still put our faith in each other. (Clinton, 2016)

The arguments of the opposition can be ridiculed by the use of popular wisdom which creates an ironic effect. The metaphoric expression "Pull yourself up by your own bootstraps" is a summary of the wording of the government and is further interpreted by the sarcastic comment "even if you don't have boots". Together with the rhetorical questions "Out of work? No health care? Born into 
poverty?" and their answers, this creates an atmosphere of dialogism between the speaker and the opposition.

(48) For over two decades, he's subscribed to that old, discredited Republican philosophy - give more and more to those with the most and hope that prosperity trickles down to everyone else. In Washington, they call this the Ownership Society, but what it really means is - you're on your own. Out of work? Tough luck. No health care? The market will fix it. Born into poverty? Pull yourself up by your own bootstraps - even if you don't have boots. You're on your own. (Obama, 2008)

\section{Opposition member's voice}

In some cases, speakers find the words of other opposition members worth mentioning because they uphold their political views. In the following excerpts the political adversary is attacked through the direct and indirect quotation. Such an attack is really strong because ideas similar to those of the speaker are expressed by a popular member of the opposition or a high-rank official.

(49) Her [Hilary's] bad instincts and her bad judgment - something pointed out by Bernie Sanders - are what caused so many of the disasters unfolding today. (Trump, 2016)

(50) When the FBI Director says that the Secretary of State [Hilary Clinton] was "extremely careless" and "negligent," in handling our classified secrets, I also know that these terms are minor compared to what she actually did. They were just used to save her from facing justice for her terrible, terrible crimes. (Trump, 2016)

\section{Titular allusion}

In an attempt to counter the arguments of the political opponent the speaker mentions the title of a book. This is a reaction to the idea that someone can fix the nation's problems all by himself, alone. The speaker upholds the opposite idea which is developed in the book.

(51) Twenty years ago I wrote a book called "It Takes a Village.” And a lot of people looked at the title and asked, what the heck do you mean by that? This is what I mean. None of us can raise a family, build a business, heal a community or lift a country totally alone. (Clinton, 2016)

\section{Numbers and research}

The use of statistical data as evidence for some deeds or misdeeds of the opposition is frequently used as a counter argument. In the following excerpts numbers and examples were sorted out not as a rational argument but rather as a construction of blame directed towards the opposition. 
(52) What about our economy? Again, I will tell you the plain facts that have been edited out of your nightly news and your morning newspaper: Nearly Four in 10 African-American children are living in poverty, while $58 \%$ of African American youth are now not employed. 2 million more Latinos are in poverty today than when President Obama took his oath of office less than eight years ago. Another 14 million people have left the workforce entirely. Household incomes are down more than $\$ 4,000$ since the year 2000. Our trade deficit in goods -- think of this -- our trade deficit reached nearly $\$ 800$ billion last year alone. The budget is no better. (Trump, 2016)

(53) We measure progress by how many people can find a job that pays the mortgage; whether you can put a little extra money away at the end of each month so you can someday watch your child receive her college diploma. We measure progress in the 23 million new jobs that were created when Bill Clinton was President - when the average American family saw its income go up $\$ 7,500$ instead of down $\$ 2,000$ like it has under George Bush.

We measure the strength of our economy not by the number of billionaires we have or the profits of the Fortune 500, but by whether someone with a good idea can take a risk and start a new business, or whether the waitress who lives on tips can take a day off to look after a sick kid without losing her job - an economy that honors the dignity of work. (Obama, 2008)

\section{Quasi-reference}

Quasi-references are examples of pseudo-intertextuality. However, they do possess certain discursive power as they manage to build arguments and persuade despite the vagueness of the statements presented. "All of the people telling you" may refer to the political opponent, to the leader of the opposition, and ordinary citizens as well. The function of this type of intertextuality is to create a dialogue between the speaker's position and a position that is unacceptable to him/her and should be refuted.

(54) Remember: All of the people telling you that you can't have the country you want, are the same people that wouldn't stand -- I mean, they said Trump doesn't have a chance of being here tonight. Not a chance! The same people. Oh, we love defeating those people, don't we? Love it, love it, love it. No longer can we rely on those same people in politics and in the media, who will say anything to keep a rigged system in place. Instead, we must choose to Believe In America. (Trump, 2016) 


\section{Conclusion}

The analysis above has shown how speakers quote different sources that function dialogically to justify the speaker's own position and suppress alternative points of view. As this study has identified a range of dialogic functions of intertextuality in acceptance speeches, it raises two fundamental questions:

\section{What type of source is more likely to be quoted in acceptance speeches?}

\section{Who quotes which source and why?}

The limited data set of this study makes it impossible to make generalizations in this regard, but there are certain tendencies in the data which will be worthwhile exploring in future research.

Table 1 shows the relative frequency by paragraph of each source used in these speeches and it reveals that the most common sources are the voices of opponents in the election campaign, the voices of ordinary citizens, and the voices of authoritative speakers or sources. This suggests that intertextuality is most likely to be deployed in order to seek solidarity and elevate one's moral standing, credibility, and thus one's ethos; and to downgrade opposing points of view.

Table 1. Instances of intertextuality classified by external speakers

\begin{tabular}{|l|l|}
\hline Quoted source & $\begin{array}{l}\text { Instances of } \\
\text { intertextuality by paragraph }\end{array}$ \\
\hline Political opponent & 25 \\
\hline Ordinary citizens & 14 \\
\hline Authoritative speaker/source & 12 \\
\hline Onomastic allusion & 9 \\
\hline Numbers and research & 5 \\
\hline Family members & 5 \\
\hline Opposition member & 2 \\
\hline Self-reference & 2 \\
\hline Quasi-reference & 2 \\
\hline Titular allusion & 1 \\
\hline Total & 77 \\
\hline
\end{tabular}

Table 2 shows the number of paragraphs with instances of intertextuality classified by speaker, revealing which speakers quote which sources. 
Table 2. Instances of intertextuality

by paragraph classified by speaker

\begin{tabular}{|c|c|c|c|c|c|c|c|}
\hline Name & $\begin{array}{l}\text { Political } \\
\text { opponent }\end{array}$ & $\begin{array}{l}\text { Ordinary } \\
\text { citizens }\end{array}$ & \multicolumn{2}{|c|}{$\begin{array}{l}\text { Authorita- } \\
\text { tive speaker/ } \\
\text { source }\end{array}$} & \multicolumn{2}{|c|}{$\begin{array}{l}\text { Onomastic } \\
\text { allusion }\end{array}$} & $\begin{array}{l}\text { Numbers } \\
\text { \& research }\end{array}$ \\
\hline Trump & 7 & 5 & 3 & & 1 & & 3 \\
\hline Clinton & 7 & 4 & 6 & & 3 & & \\
\hline Obama & 6 & 3 & 3 & & 2 & & 2 \\
\hline McCain & 5 & 2 & & & 3 & & \\
\hline Total & 25 & 14 & 12 & & 9 & & 5 \\
\hline Name & $\begin{array}{l}\text { Family } \\
\text { members }\end{array}$ & $\begin{array}{l}\text { Opposition } \\
\text { member }\end{array}$ & \begin{tabular}{|l} 
Self-ref- \\
erence
\end{tabular} & $\begin{array}{l}\text { Qua } \\
\text { refer } \\
\text { ence }\end{array}$ & & $\begin{array}{l}\text { Titular } \\
\text { allusion }\end{array}$ & Total \\
\hline Trump & 1 & 2 & 2 & 2 & & & 26 \\
\hline Clinton & 1 & & & & & 1 & 22 \\
\hline Obama & 1 & & & & & & 17 \\
\hline McCain & 2 & & & & & & 12 \\
\hline Total & 5 & 2 & 2 & 2 & & 1 & 77 \\
\hline
\end{tabular}

On the basis of these results, a few remarks can be made. First, the most frequent type of intertextuality with the four speakers is citing the political opponent. In fact this type of intertextuality serves as an underlying principle for text organization and construction of arguments in the speeches. Second, reference to the words or reports of the encounters with ordinary citizens is typical for the acceptance speeches, especially those from the second period. These two observations may be explained by the general tendency towards popular speaking and appeal to pathos. Referring to family members is another instance of intertextuality which remains as a typical feature which legitimizes the existential coherence of the speakers. Given the formality of the occasion it can be expected that speakers may identify themselves with the authority of national heroes and important documents. These instances of intertextuality are obvious with only one of the speakers, giving the speech more pathos and less authenticity. Referring to national and cultural symbols may put the speech within the rhetorical presidential tradition but could be a delicate matter as such intertextual links have been used a lot and are well remembered. What strikes one as a novel way to use intertextuality is the reference to numbers and research. These instances show how objective data can be used manipulatively. Both speakers who used this strategy never mentioned the sources or the producers of the statistics and arranged the information to be revealed by intensifying the negative results and mitigating the positive ones. What is more, speakers used, arguably, objectivity and rationality to create a feeling of fear and anxiety, i.e. irrationality. This was achieved by the accumulation of numbers in combination with lexical choice of words from the semantic field of death. Quasi-reference is another example of a manipulative use of intertextuality as it hides the 
producer of the text cited or rather constructs artificial dialogism. There are three more instances of intertextuality within the corpus. Those instances are quite interesting because they represent a rhetorical effort at finding various and novel ways to legitimize. The self-reference instances of intertextuality and titular allusion, i.e. the citation of the title of one's own book, are very similar as an effective and cogent strategy to establish the authority of the speaker without the need of overt epistemic modality. Another deployment of intertextuality is the quotation of an opposition member who endorses the same comments made by the speaker. This presents the speaker as wise and credible while the claims of the opponent are downgraded. Such a communicative situation creates discursive polarization between the speaker and his/her opponent and can be explained by van Dijk's “ideological square” (2006b).

\section{Implications}

This study has shown that authority legitimation can be achieved through intertextuality along with other linguistic resources. The problem with this means of legitimation is that intertextuality is a text reception phenomenon, it relies strongly on the text receiver's preparedness to interpret texts and cultural frames. On the one hand, the issue of preparedness is easily resolved as this genre of political speeches is mainly directed towards possible voters within the country who are expected to be knowledgeable of recent political events and past historical moments. On the other hand, with regard to the reception of political discourse, the text reading is not at all a private or individual activity but a publicly mediated global event. For instance, all the acceptance speeches from the corpus are available to an international audience through the Internet and the social media. However, if students or users of English desire to approach them as text recipients, their lack of cultural knowledge and preliminary guidance on political and cultural pre-texts might hinder their relevant interpretation of the message. This proves that authority legitimation is an interaction strategy. It is based on shared beliefs and values and is continuously negotiated in communication.

\section{References:}

Aristotle (1986). Retorika. Sofia: Science and art.

Austermühl, F. (2014). The great American scaffold: Intertextuality and identity in American presidential discourse. Amsterdam/Philadelphia: John Benjamins.

Cap, P. (2006). Legitimization in political discourse. A cross-disciplinary perspective on the modern US war rhetoric. Newcastle: Cambridge Scholars Press. 
Chilton, P. (2004). Analysing political discourse: Theory and practice. London/ New York: Routledge.

Fairclough, N. (1992). Discourse and text: linguistic and intertextual analysis within discourse analysis. Discourse \& Society, 3(2), 193-217.

Fairclough, N. (2003). Analysing discourse: Textual analysis for social research. London/New York: Routledge.

Fairclough, I., \& Fairclough, N. (2012). Political discourse analysis: A method for advanced students. London: Routledge.

Habermas, J. (1984). The theory of communicative action (Vol. 1). London: Heinemann.

Heywood, A. (2007). Politics ( $3^{\text {rd }}$ ed.). Basingstoke: Palgrave Macmillan.

Lakoff, G. (1996). Moral Politics: How Liberals and Conservatives think. Chicago, IL: University of Chicago Press.

Mackay, R. (2015). Multimodal legitimation: Selling Scottish independence. Discourse \& Society, 26(3), 323-348.

Martin Rojo, L. \& van Dijk, T. A. (1997). "There was a problem and it was solved!": Legitimating the expulsion of 'illegal' migrants in Spanish parliamentary discourse. Discourse \& Society, 8(4), 523-566.

Oxford English Dictionaries. Available at: http://en.oxforddictionaries.com

Reyes, A. (2011). Strategies of legitimization in political discourse: From words to actions. Discourse \& Society, 22(6), 781-807.

Van Dijk, T. A. (2006a). Discourse and Manipulation. Discourse \& Society, 17(3), 359-383.

Van Dijk, T. A. (2006b). Politics, ideology, and discourse. In K. Brown (Ed.), Encyclopedia of language and linguistics (Vol. 9) (pp. 728-740). Oxford: Elsevier.

Van Leeuwen, T. (2007). Legitimation in discourse and communication. Discourse \& Communication, 1(1), 91-112.

Van Leeuwen, T., and R. Wodak. (1999). Legitimizing immigration control: discourse-historical approach. Discourse Studies, 1(1), 83-118.

Wodak, R. (2018). "Strangers in Europe". A discourse-historical approach to the legitimation of immigration control 2015/16. In S. Zhao, E. Djonov \& A. Björkvall (Eds.), Advancing Multimodal and Critical Discourse Studies (pp. 31-50). London: Routledge. 


\section{List of speeches analyzed:}

Clinton, H. (2016). Address accepting the presidential nomination at the Democratic National Convention in Philadelphia, Pennsylvania. In G. Peters \& J. T. Woolley (Eds.), The American Presidency Project. Retrieved from: https://www.presidency.ucsb.edu/node/317862

McCain, J. (2008). Address accepting the presidential nomination at the Republican National Convention in Saint Paul. In G. Peters \& J. T. Woolley (Eds.), The American Presidency Project. Retrieved from: https://www. presidency.ucsb.edu/node/279091

Obama, B. (2008). Address accepting the presidential nomination at the Democratic National Convention in Denver: "The American Promise“. In G. Peters \& J. T. Woolley (Eds.), The American Presidency Project. Retrieved from: https://www.presidency.ucsb.edu/node/278860

Trump, D. (2016). Address accepting the presidential nomination at the Republican National Convention in Cleveland, Ohio. In G. Peters \& J. T. Woolley (Eds.), The American Presidency Project. Retrieved from: https:// www.presidency.ucsb.edu/node/318521 